\title{
Field Trials of Plum Clones Transformed with the Plum pox virus Coat Protein (PPV-CP) Gene
}

T. Malinowski, Instytut Sadownictwa i Kwiaciarstwa, Skierniewice, Poland; M. Cambra and N. Capote, Instituto Valenciano de Investigaciones Agrarias (IVIA), Valencia, Spain; B. Zawadzka, Instytut Sadownictwa i Kwiaciarstwa; M. T. Gorris, IVIA; R. Scorza, United States Department of Agriculture-Agricultural Research Service, Appalachian Fruit Research Station, Kearneysville, WV; and M. Ravelonandro, Institut de Biologie Vegetale et Moleculaire, INRA, Bordeaux, France

\begin{abstract}
Malinowski, T., Cambra, M., Capote, N., Zawadzka, B., Gorris, M. T., Scorza, R., and Ravelonandro, M. 2006. Field trials of plum clones transformed with the Plum pox virus coat protein (PPV-CP) gene. Plant Dis. 90:1012-1018.

Transgenic clones C2, C3, C4, C5, C6, and PT-6, of plum (Prunus domestica L.) transformed with the coat protein (CP) gene of Plum pox virus (PPV), PT-23 transformed with marker genes only, and nontransgenic B70146 were evaluated for sharka resistance under high infection pressure in field trials in Poland and Spain. These sites differed in climatic conditions and virus isolates. Transgenic clone C5 showed high resistance to PPV at both sites. None of the C5 trees became naturally infected by aphids during seven (Spain) or eight (Poland) years of the test, although up to $100 \%$ of other plum trees (transgenic clones and nontransgenic control plants) grown in the same conditions showed disease symptoms and tested positively for PPV. Although highly resistant, $\mathrm{C} 5$ trees could be infected artificially by chip budding or via susceptible rootstock. Infected C5 trees showed only a few mild symptoms on single, isolated shoots, even up to 8 years post inoculation. These results clearly indicate the long-term nature and high level of resistance to PPV obtained through genetically engineered resistance.
\end{abstract}

Additional keywords: PDR, Sharka disease, transgenic plum

Plum pox virus (PPV) (family: Potyviridae, genus: Potyvirus) is the causal agent of plum pox disease (sharka), one of the most important diseases affecting commercial stone fruit (Prunus spp.), including plum, apricot, and peach (17). The virus was first reported in Bulgaria in the early 20th century (3) and has spread since then throughout Europe. More recently it has been reported from Chile (1) and from North America (United States and Canada; $13,25)$. The virus is naturally transmitted by aphids in a nonpersistent manner (10). Due to the efficient spread of PPV by aphids, the presence of many potential hosts in both orchards and surrounding areas, and inconspicuous symptoms in some species and cultivars, sharka disease is difficult to eliminate once it has become established in an area. The control of PPV is based mainly on quarantine measures, including destruction of infected trees. However, it seems that a more costeffective and durable solution could be achieved by growing PPV-resistant culti-

Corresponding author: T. Malinowski

E-mail:tmalin@insad.pl

Accepted for publication 12 March 2006.

DOI: 10.1094/PD-90-1012

(C) 2006 The American Phytopathological Society vars, especially in the areas where sharka has been present.

Breeding programs have exploited naturally occurring resistance; however, due to the long-term nature of tree fruit breeding and polygenic inheritance of natural PPV resistance, few highly resistant commercial cultivars have been introduced successfully $(11,18)$. Because the disease continues to spread and cause serious losses to stone fruit production, an alternative or complementary approach to traditional resistance breeding was initiated based on pathogenderived resistance (PDR; 21). Transgenic clones of Prunus domestica were produced by Agrobacterium sp. transformation of plum hypocotyls with the PPV coat protein (CP) gene (23). One clone (C5) was found to be highly resistant to the virus under glasshouse conditions (19). Field trials have been carried out in Poland, Romania, and Spain to verify those results under high infection pressure (natural presence of viruliferous aphids) and to evaluate the durability of PDR. Preliminary results indicated that C5 was not infected by aphid vectors present in all experimental fields. Although when artificially inoculated with chip buds, C5 trees became infected but showed only a few mild symptoms on isolated shoots $(9,16,20)$.

Here, we report the long-term results of field resistance trials of several transgenic plum clones conducted in plots located in
Poland and Spain in areas of high PPV infection pressure. The field plots differed in PPV isolates, aphid-vector species, and climatic conditions, yet, in both tests, the C5 clone exhibited a high level of resistance that has lasted for more than 7 years (Spain) and 8 years (Poland). The results obtained in Romania (20) also are briefly discussed.

\section{MATERIALS AND METHODS}

Plant material. Transgenic clones were selected for field testing based on differential sensitivity to PPV in greenhouse tests (19). Clones C2, C3, C4, C5, and C6 were tested in Poland. In Spain, C4, C5, C6, PT6, and PT23 were evaluated. All transgenic clones contained the PPV-CP gene except PT23, which contained only the marker genes of neomycin phosphotransferase II (nptII) and $\beta$-glucoronidase (GUS) in common with the other transgenic clones $(22,23)$. All transgenic clones and untransformed clone B70146 were propagated on virus-free $P$. marianna (GF 8-1) rootstocks at one location (France) and distributed to both experimental plots. Untransformed susceptible control cultivars were $P$. domestica clone B70146 (Spain and Poland), and Sweet Common Prune (Węgierka Zwykła; Poland) or $P$. salicina Black Diamond (Spain) grafted on P. cerasifera.

Field plot designs. The design of both experimental plots is shown in Figure 1.

Poland. In all, 10 trees each of the transgenic clones: $\mathrm{C} 2, \mathrm{C} 3, \mathrm{C} 4, \mathrm{C} 5, \mathrm{C} 6$ and nontransformed B70146 were planted in April 1996, together with 60 trees of the highly susceptible cv. Sweet Common Prune. The susceptible cultivar was planted as every second tree and chip bud inoculated in August 1996 to serve as a virus inoculum reservoir. Two trees of each tested clone also were inoculated by grafting two infected bark chips into the rootstock. The eight remaining trees of each clone were left for natural aphid inoculation. A tree infected with D-type isolate PPV-S (syn. PPV-Skierniewice; 27) was used as a source of infected bark chips. In addition to the inoculated PPV-susceptible control trees, other infected plum trees were located in field plots adjacent (within $100 \mathrm{~m}$ ) to the test plot, and additional infected plants had been found in the area 
within a radius of several kilometers. The climate in Poland is temperate. During 1997 to 2004 , the monthly mean temperatures in the plot in April ranged from $5.4^{\circ} \mathrm{C}$ in 1998 to $12^{\circ} \mathrm{C}$ in 2000 , in May from $12.5^{\circ} \mathrm{C}$ in 2004 to $17.1^{\circ} \mathrm{C}$ in 2002 , and in June from $15.4^{\circ} \mathrm{C}$ in 2001 to $18.2^{\circ} \mathrm{C}$ in 2003.

Spain. One hundred plum trees were planted in April 1997 in an irrigated ex- perimental plot located in the area of Líria, Valencia. Half of the total trees were transgenic clones (C4, C5, C6, PT6, and PT23) planted in five-tree rows (two rows per clone). The remainder of the trees were nontransgenic plum (B70146 on $P$. marianna and $P$. salicina 'Black Diamond' on $P$. cerasifera) planted between transgenic rows. In all, 25 nontransformed plum trees were graft inoculated with bark chips containing PPV $3.3 \mathrm{RB} / \mathrm{GF}$ Mp15/GF strain (2), reacting with $\mathrm{D}$-specific monoclonal antibody (MAb) 4DG5 but defective in the epitope recognized by the MAb 4BD7 $(6,14)$. The plot in Spain represented a Mediterranean climate. During the experimental period (1997 to 2003), the average of mean temperatures registered in
A) 1996 - planting and chip bud inoculation

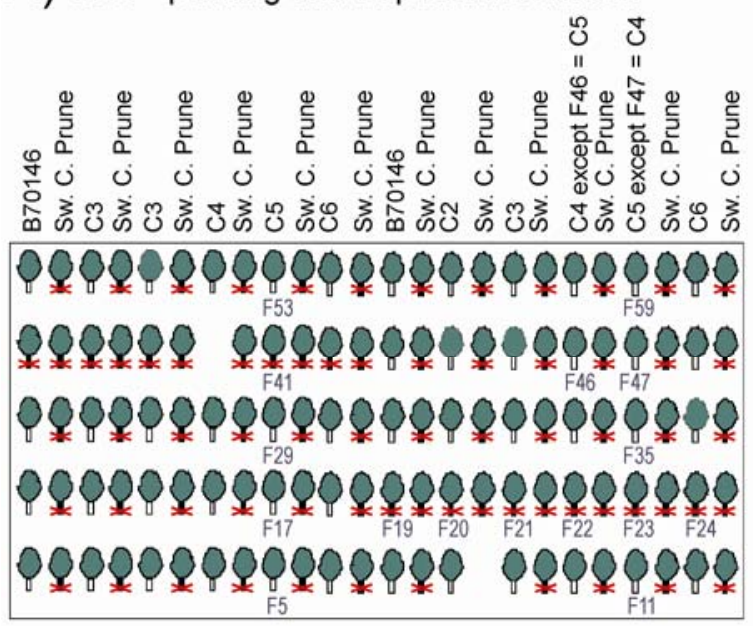

B) 1997 - planting and graft inoculation

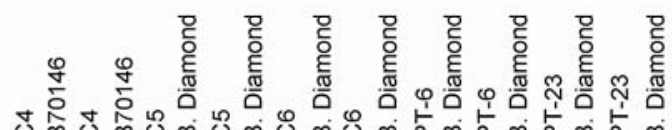

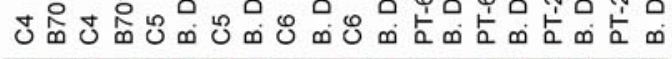

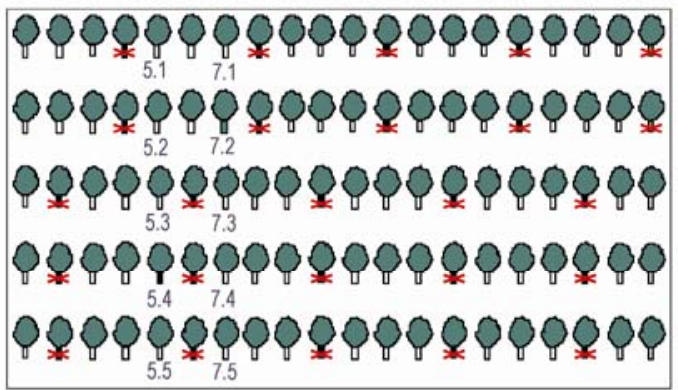

2003

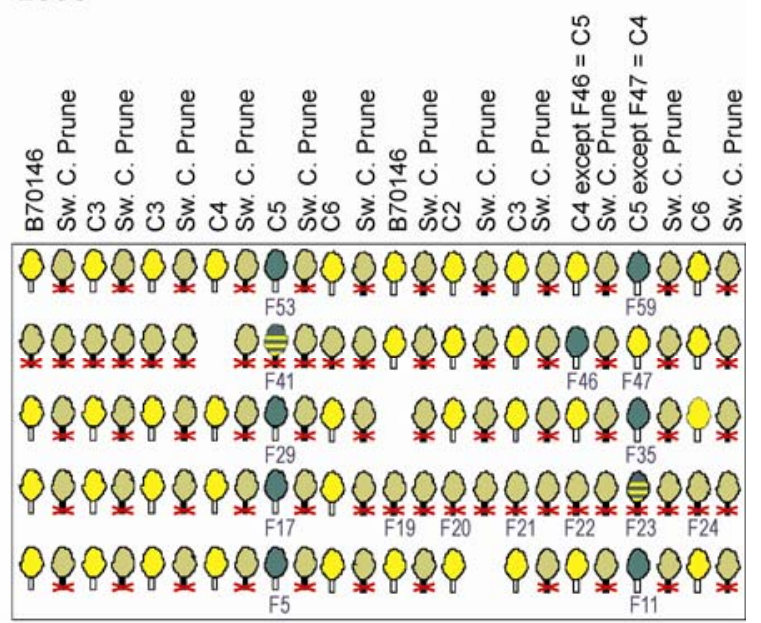

2004

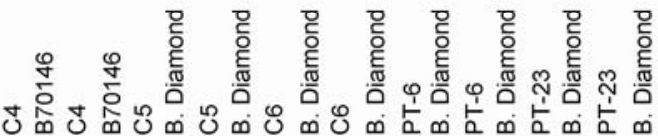

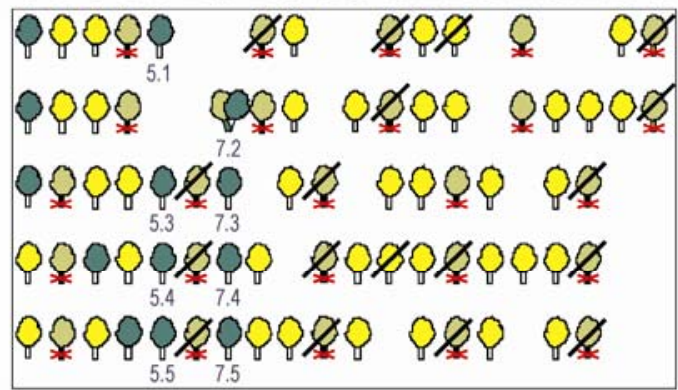

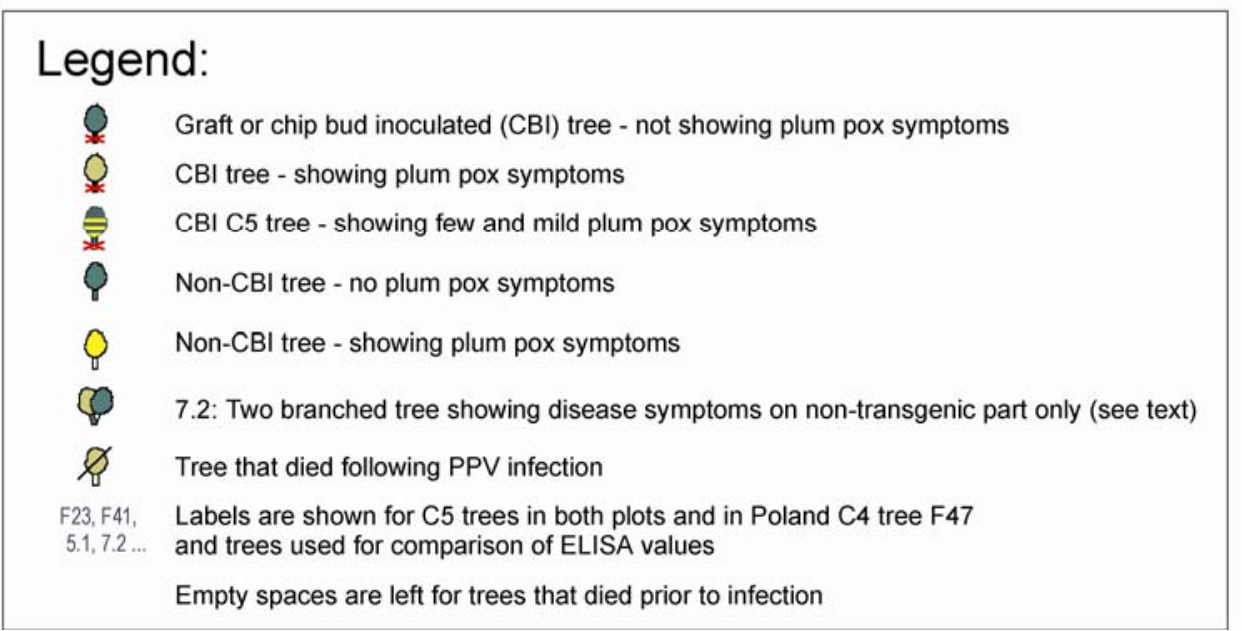

Fig. 1. Design of the experimental plots in $\mathbf{A}$, Poland and $\mathbf{B}$, Spain and progress of the disease 7 years after planting and inoculation of selected trees. After 7 years at both test sites, only C5 trees and some C4 ones in Spain remained free from Plum pox virus (PPV). ELISA = enzyme-linked immunosorbent assay. 
the plot were $15^{\circ} \mathrm{C}$ in spring, $24^{\circ} \mathrm{C}$ in summer, $16.6^{\circ} \mathrm{C}$ in autumn, and $9.5^{\circ} \mathrm{C}$ in winter, reaching a mean maximum of $30.9^{\circ} \mathrm{C}$ in summer season and a mean minimum of $3.5^{\circ} \mathrm{C}$ in winter. The relative humidity varied between 58 and $68 \%$ in summer and autumn, respectively. Solar radiation was maximal in summer, with an average value of $293 \mathrm{~W} / \mathrm{m}^{2}$, and minimal in winter, reaching $102 \mathrm{~W} / \mathrm{m}^{2}$.

Sanitary status, agricultural practices, and aphid species monitoring. Trees in both locations were evaluated in the first year for the presence of Prunus necrotic ring spot virus, Prune dwarf virus, Apple chlorotic leaf spot virus, and
Apple mosaic virus using enzyme-linked immunosorbent assay (ELISA) with reagents either prepared in individual laboratories or from commercially available kits from Loewe Biochemica (Germany). In Poland, these tests were repeated in 2003. All trees tested negative. Agricultural practices considered standard for each area were utilized for maintenance of the trees, except that the use of insecticides was limited in order to allow for robust aphid populations. In Poland, all flower buds were removed from trees until 2003, at which time authorization was granted by the Ministry of Environment to allow open flowering in the experimental plot. In 2001

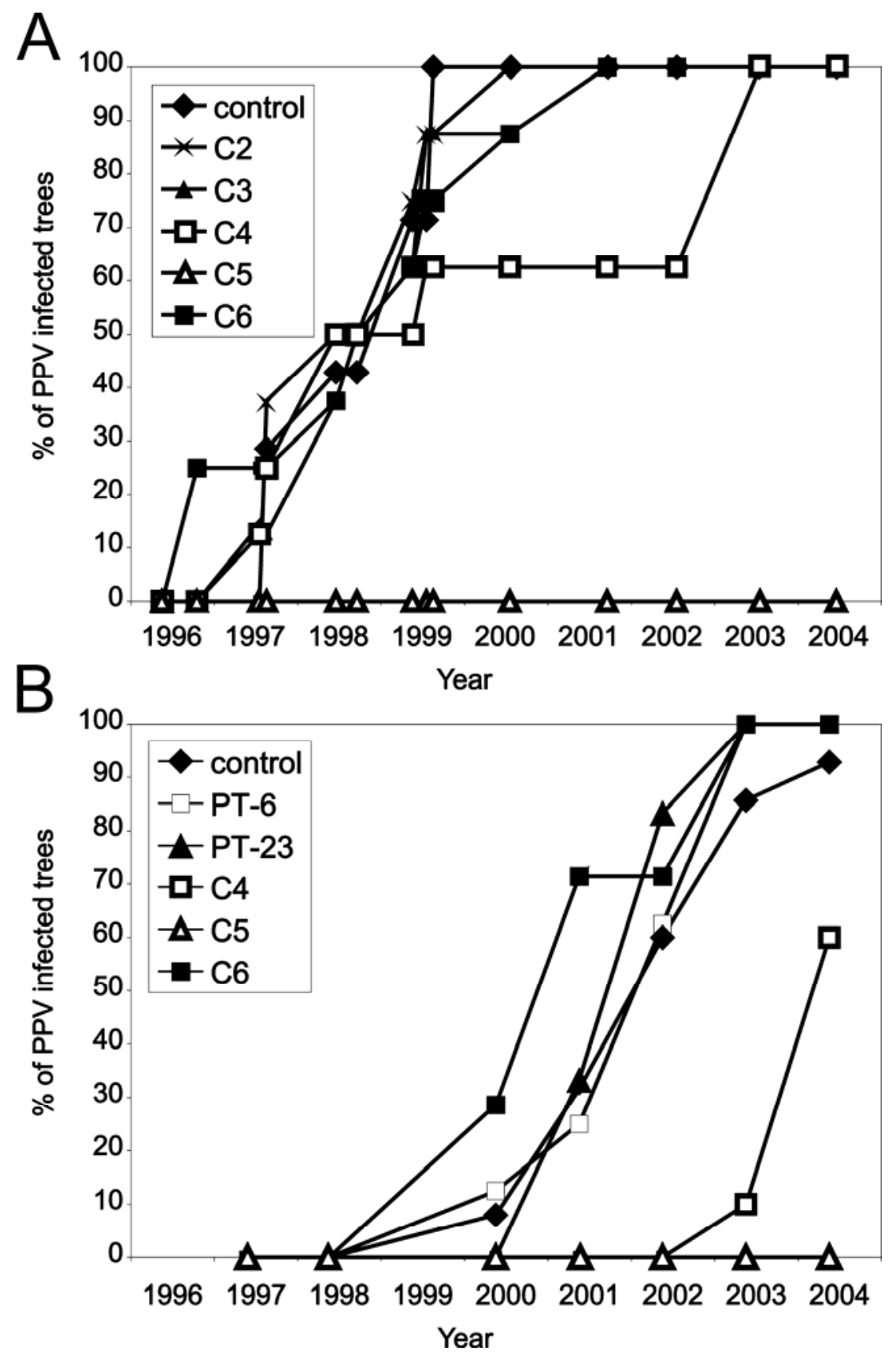

Fig. 2. Temporal spread of Plum pox virus (PPV) in transgenic plum trees and controls exposed solely to aphid-vectored virus transmission in the experimental field plots in A, Poland (control is nontransformed European plum, Prunus domestica B70146) and B, Spain (control is Japanese plum, P. salicina 'Black Diamond').

and 2002 , trees were severely pruned during the spring to reduce the hand labor necessary for flower removal. Visual observations in both experimental plots verified aphid presence and feeding. In Spain, the "sticky shoot" method, based on covering selected shoots with a special glue (4), was used for screening the population of insects visiting the trees.

Monitoring of $P P V$ infection and identification of virus isolates. Detailed visual observations were performed at least twice a year in Poland (June or July and August or September, depending on the development of symptoms on the control trees) and once a year (May) in Spain. Leaf samples for serological analyses were collected at these dates. Sampling for virus presence in test trees was performed in two tiers. Samples from trees with symptoms or suspected symptoms consisted of at least four to six of the symptom-expressing leaves. Leaf or shoot samples from trees with no apparent symptoms were collected randomly from at least four branches spaced evenly around the canopy with a total of at least eight leaves per tree. Samples were tested for the presence of PPV by ELISA. Double-antibody sandwich (DAS)-ELISA using polyclonal antibodies from locally prepared antisera or commercial kits (Loewe, Germany) and doubleantibody sandwich indirect (DASI)-ELISA using the MAb 5B-IVIA (Agritest, Italy or Durviz, Spain; 6) were applied for PPV detection according to standard protocols. PPV isolates in the experimental plot were serotyped with several MAbs: 5B, 4DG5, 4DG11, and 4BD7 (6); AL (5); and V/8 and V/13 (T. Malinowski, B. Zawadzka, and A. Porębska, unpublished data). Absorbances were measured at two wavelengths (405 and $630 \mathrm{~nm}\left[A_{405}\right.$ and $A_{630}$, respectively]) in ELISA to reduce the background. The difference $\left(A_{405}-A_{630}\right)$ was used for further calculations and comparisons. Positive or negative threshold was established as the mean reading for negative controls plus three standard deviations (8).

To confirm the PPV-free status of samples that exhibited negative ELISA values and to critically analyze for the presence of virus in clone C5 or other samples with low ELISA readings, total RNA from the putatively healthy plants was isolated through silicacapture or by means of the RNeasy Plant Mini Kit (Qiagen, Inc., Valencia, CA). In Poland, silicacapture reverse-transcription (RT)-PCR (15) and immunocapture (IC)-RT-PCR (26) were applied. Detection was based on primers PPV-A/PPV-B (12) targeting the 5 ' end fragment of the NIb gene. In Spain, RTPCR with primers homologous to the $3^{\prime}$ terminal sequence of the NIb gene and the $5^{\prime}$ terminal sequence of the $\mathrm{CP}$ gene, primers 80 (5'-TTGGGTTCTTGAACAAGC$\left.3^{\prime}\right)$ and 82 (5'-TGGCACTGTAAAAGT TCC-3') (provided by Dr. J. A. García, CNB, Madrid) and IC-RT-PCR using the 
P1 and P2 primers (26) targeting the $3^{\prime}$ end fragment of $\mathrm{CP}$ gene were carried out to detect viral cDNA.

\section{RESULTS}

PPV infection pressure, virus isolates, and aphid species. Natural infection pressure was high in both experimental orchards. All chip-bud-inoculated (CBI) trees that were used as a primary inoculum source (B70146, Black Diamond, and Sweet Common Prune) showed diagnostic leaf symptoms and tested positive for PPV in ELISA the year following chip bud inoculation. The species of aphids observed on experimental trees in Poland were Brachycaudus helichrisi, B. cardui, and Hyalopterus pruni. In the experimental plot located in Spain, aphids trapped onto sticky shoots in spring 2003 consisted of Aphis spiraecola, A. gossypii, $H$. pruni, B. prunicola, A. craccivora, Myzus persicae, and other minor species.

All virus isolates in both plots reacted with universal and D-specific MAb but did not react with the M-specific MAb, indicating that trees were infected with D-type isolates. More detailed analyses of the sero- type using several MAbs showed the presence of isolates belonging to at least three serotypes (subtypes of D-type) among the population of PPV in the experimental plot in Poland and at least two serotypes (subtypes of D-type) in Spain. In Poland, in addition to PPV-S, which was used for inoculation of test plants, isolates with serological properties represented by PPV-AlN and PPV-F33 were identified based on the pattern of reaction with $\mathrm{MAb} \mathrm{V} / 8$ and $\mathrm{MAb}$ $\mathrm{V} / 13$. Isolate $\mathrm{PPV}-\mathrm{S}$ reacted with MAb V/8 and MAb V/13, PPV-AlN was recognized by MAb V/8 but not by MAb V/13, and PPV-F33 was detected by MAb V/13 but not MAb V/8. PPV-AlN had been found earlier in naturally infected trees growing a few kilometers from the experimental field.

A switch from a pattern of serological reaction typical for PPV-AIN (MAb V/13 negative) or PPV-F33 (MAb V/8 negative) to the pattern represented by PPV-S (both MAb V/8 and MAb V/13 positive) was observed for single trees in 2001-04.

Two different D-subtype serotypes of PPV were detected in the Spanish plot. The first, characterized as MAb 4BD7negative, was shown by PPV $3.3 \mathrm{RB} / \mathrm{GF}$
Mp15/GF (2) introduced to the field by inoculation. Trees showing positive reactions against MAb 4DB7 probably were infected with PPV isolates originating from the surrounding naturally infected plots (data not shown).

Resistance assays-natural aphid transmission. Infection pressure was high in Poland, with $100 \%$ of the trees of clones B70146, C2, C3, C4, and C6 found to be infected in 2003, 7 years after initiation of the field trial (Fig. 1A). In fact, all B70146, C2, and C3 trees were infected already in 2001, which is within 5 years from the beginning of the experiment (Fig. 2A). Infected trees of transgenic clones C2, C3, C4, and C6, as well as nontransformed control B70146, displayed definite PPV symptoms and were ELISA positive. The typical pattern of temporal symptom development was the appearance of chlorotic patterns on leaves on one branch in the first year followed by invasion of the entire tree in the following 1 to 2 years. All C5 trees exposed only to natural infection remained free from PPV, as verified through visual observation, ELISA, and IC-RT-PCR (Fig. 3A, lanes 1, 2, 3, 5, 6, 8,
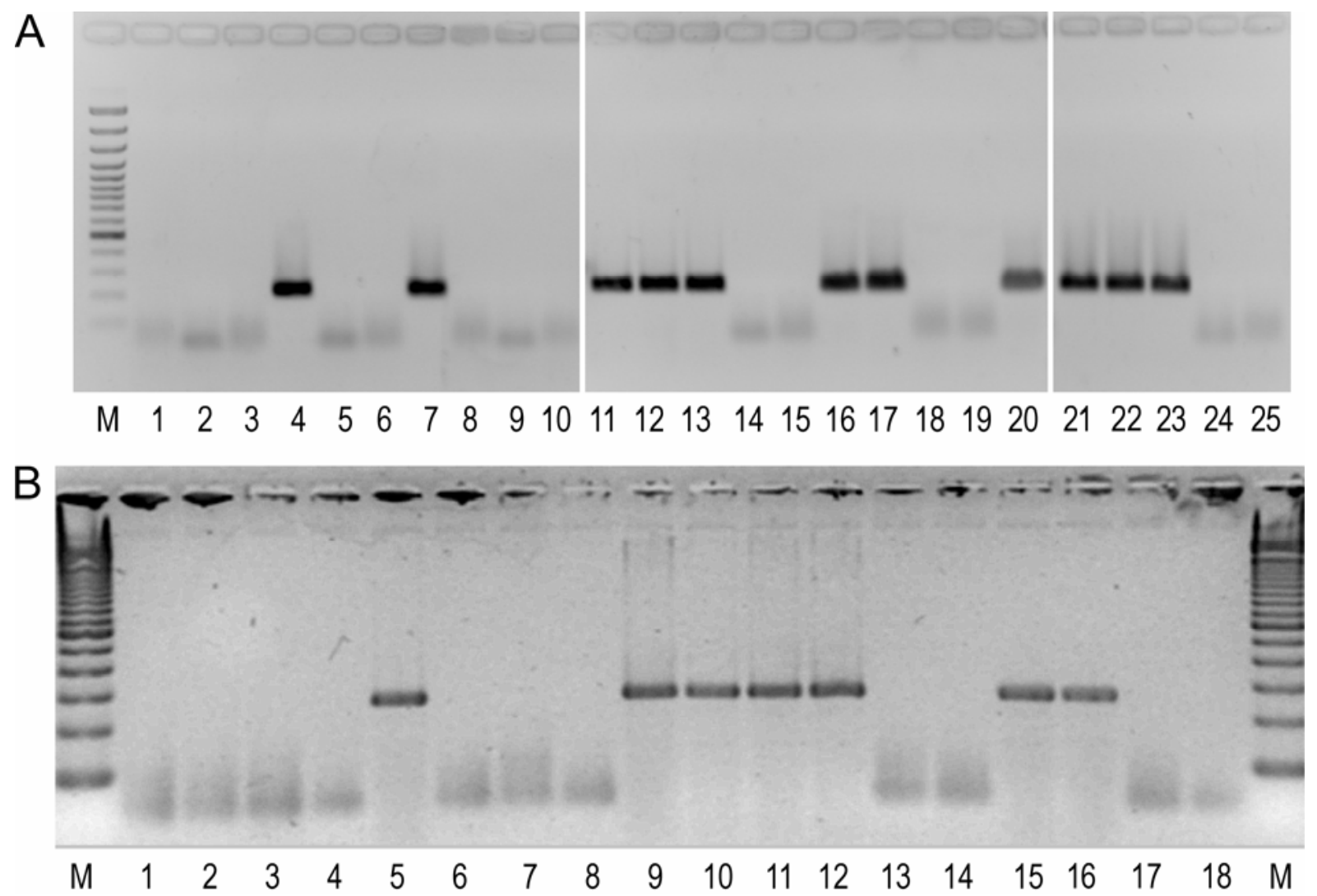

Fig. 3. Immunocapture reverse-transcription polymerase chain reaction detection of Plum pox virus (PPV) in C5 clone trees after 8 or 7 years in the field. A, Experimental plot in Poland, 8 years after planting, primers PPV A and PPV B (12). Lane M, 100-bp DNA Ladder Plus (Fermentas); lanes 1 to 10, mixed leaf samples from several branches of individual C5 trees; lane 1, F5; lane 2, F11; lane 3, F17; lane 4, F23 (chip-bud-inoculated [CBI] tree); lane 5, F29; lane 6, F35; lane 7, F41 (CBI tree); lane 8, F46; lane 9, F53; lane 10, F59; lanes 11 to 15, individual leaves from CBI tree F23; lanes 16 to 20, individual leaves from CBI tree F41; lanes 21 to 23 , positive controls, plum trees infected with three different isolates of PPV; lanes 24 to 25 , negative controls, healthy plum. B, Experimental plot in Spain, 7 years after planting, primers PPV P1 and PPV P2 (26). Lane M, 100-bp DNA Ladder (Invitrogen); lanes 1 to 4 and 6 to 8, mixed leaf samples from several branches of individual C5 trees; lane 1, tree 5.1; lane 2, tree 5.3; lane 3, tree 5.4; lane 4, tree 5.5; lane 5, symptomatic spur from tree 7.2; lane 6, tree 7.3; lane 7, tree 7.4; lane 8, tree 7.5; lanes 9 to 12, samples from Prunus marianna root suckers of C5 trees; lane 9, tree 5.5; lane 10, tree 7.2; lane 11, tree 7.3; lane 12, tree 7.5; lanes 13 to 14, samples from nonsymptomatic sections of the C5 tree 7.2; lanes 15 to 16 , positive controls, plum trees infected with two different isolates of PPV; lanes 17 to 18, negative controls, healthy plum trees. 
9, and 10 and $\mathrm{B}$, lanes $1,2,3,4,6,7,8$, 13 , and 14).

Within 7 years in Spain, $100 \%$ of susceptible clones C6, PT-6, and PT-23, as well as nearly all nontransformed control trees, were infected (Fig. 1B). Clone C4 exhibited a delay in infection, remaining uninfected 5 years after inoculation. The first detection in one C4 tree was in 2003, 6 years after orchard establishment and, by 2004, 6 of $10 \mathrm{C} 4$ trees were infected, as checked by visual observations, ELISA and IC-RT-PCR (Fig. 2B).

Resistance assays-chip bud inoculation. All CBI susceptible-cultivar trees (Sweet Common Prune in Poland and Black Diamond in Spain) showed clear symptoms of sharka disease and tested positive for PPV by ELISA in the next season after artificial infection. In addition, trees of clones B70146, C2, C3, C4, and C6 that were chip budded in Poland showed symptoms in the first growing season following inoculation and were ELISA positive. The first symptoms on CBI C5 trees were found 2 years after inoculation, 1 year later than on the other clones. Only a few leaves on a few shoots displayed chlorotic patterns. The chlorosis usually was much less pronounced than on leaves of the other transgenic clones and the nontransformed control. Symptoms observed for each clone are shown in Fig-
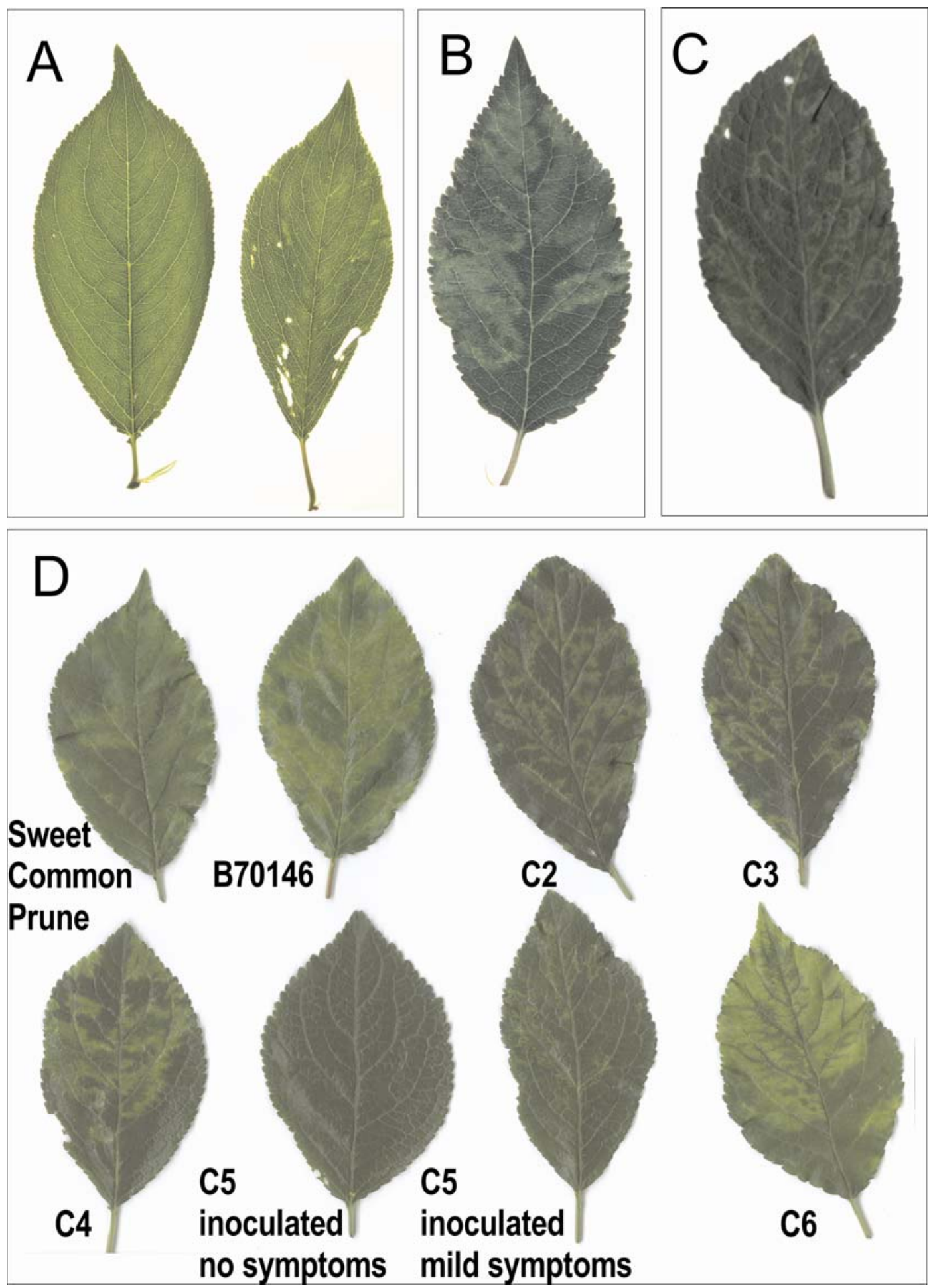

Fig. 4. Leaf symptoms caused by Plum pox virus. Susceptible plum cultivars: A, Black Diamond and B, Sweet Common Prune. C, First leaf symptoms observed in 1998 on chip-bud-inoculated C5 tree number F23. D, Symptomatic leaves collected from transgenic plum clones 8 years after inoculation in 2004. Symptoms on the C5 clone were mild and appeared on only a few leaves. 
ure 4. Characteristic symptoms are difficult to see on Black Diamond control trees used in Spain in spite of a high concentration of the virus. In the case of inoculated C5 trees, even extremely mild symptoms were not always present in consecutive years on the same shoots. The mildest symptoms were infrequently observed (less than five symptomatic leaves per tree) on inoculated C5 trees in 2000 and 2003. The spread of infection to all branches with most leaves showing typical symptoms of sharka, a pattern typical for sensitive cultivars, was not observed. Although symptoms were not limited to a small area close to the inoculation point (see below), most leaves on the shoots other than those showing symptoms were not only symptomless and ELISA negative, but IC-RTPCR negative as well (Fig. 3A, lanes 14, 15,18 , and 19). ELISA values for symptomatic leaves of CBI C5 trees were consistently lower than those obtained for any other clone, indicating effective inhibition of virus multiplication. Transgenic trees were not CBI in Spain.

Infection through susceptible rootstocks. The rootstock $P$. marianna GF 8-1 used for propagation of tested trees had a tendency to produce shoots from roots (root suckers). In both locations, root suckers were eliminated rigorously in the first 3 years of the experiment but, later, were removed once or twice per year and tested for PPV. Virus was confirmed by ELISA in root suckers of all trees showing infection in the canopy (data not shown). Additionally, infection of root suckers was detected in both plots by ELISA and RTPCR for several C5 trees.

In Poland, root suckers of trees F5, F29, F35, F53, and F59 were determined to be infected in 2002; F5, F17, F29, F35, and F53 in 2003; and F17, F29, F35, and F53 in 2004. The high ELISA absorbance values obtained from infected leaf samples collected from root suckers of these trees were similar to those from other clones, nontransgenic controls, and transgenic susceptible clones (data not shown). Noninoculated C5 trees growing on rootstock with PPV-infected root suckers, including F17, F29, F35, and F53 grown on rootstocks showing infection of suckers in two consecutive years, remained symptomless and were ELISA and RT-PCR negative for PPV when tested in June 2004 (Fig. 3A, lanes 3, 5, 6, and 9).

In Spain, four of eight C5 trees (two other C5 trees died due to fungal infection) contained the virus in root suckers (Fig. 3B, lanes 9, 10, 11, and 12). No PPV was detected in the $\mathrm{C} 5$ scion of three of these four trees (Fig. 3B, lanes 4, 6, and 8). Tree C5 number 7.2 presented a unique case. A shoot from the $P$. marianna rootstock in this tree had grown considerably, having failed to be eliminated in earlier years. Its growth was allowed to continue until it reached a size similar to that of the $\mathrm{C} 5$ branch. This produced a double-branched tree, one-half from rootstock and one-half from scion. In 2002, symptoms of PPV infection were observed for the first time on leaves of the nontransgenic section of the tree. Infection was confirmed by ELISA. In the following year (2003), mild PPV symptoms were observed for the first time in some C5 spurs located at the bottom part of the trunk very near to the point of union between the P. marianna rootstock and the C5 scion. Symptomatic leaves collected from those $\mathrm{C} 5$ spurs were positive by ELISA, RT-PCR, and IC-RT-PCR (Fig. 3B, lane 5). ELISA absorbance values of C5 samples were three times lower than those of the P. marianna samples from the same tree when analyzed during the winter (data not shown). The remainder of the $\mathrm{C} 5$ branch of tree 7.2 remained PPV free (Fig. 3B, lanes 13 and 14). We were unable to detect PPV in the other C5 plants, including C5 scions growing on infected rootstocks (Fig. $3 \mathrm{~B}$, lanes 4,6 , and 8 ).

\section{DISCUSSION}

The high resistance of the C5 clone against aphid-vectored PPV was observed independently at two different locations with several different isolates of PPV and different climatic conditions. These results were further corroborated by a field test in Romania (20), where both PPV-D and PPV-M isolates were naturally present and none of the $\mathrm{C} 5$ trees became infected during 6 years of exposure to infection pressure in the field. In experiments described here, at least five PPV isolates belonging to different D-subtypes were detected in trees evaluated. Most trees became infected with the isolates used for inoculation of "virus source" trees, including PPV-S (in Poland) and PPV $3.3 \mathrm{RB} / \mathrm{GF}$ Mp15/GF (in Spain). Several trees, for which a switch of the profile of reaction with MAbs was observed, must have become co-infected with at least two different strains of PPV. In our study, the identification of serological subtypes was based on lack of reaction with some MAbs rather than positive identification with MAbs recognizing an epitope specific for just one strain; therefore, it cannot be excluded that some other trees also were co-infected with several different variants of PPV. The diversity of PPV population in transgenic plum trees was a subject of another study based on the analysis of sequence variants in virus populations (7).

Infection pressure in the experimental field plots in both Poland and Spain was adequate to ensure the natural spread of PPV to 100\% (in Poland) and over 93\% (in Spain) of susceptible nontransformed controls by the end of the 7- to 8-year test period. Under these conditions, no C5 trees exposed to aphid feeding alone became infected with PPV.

Both CBI C5 trees F23 and F41 in Poland and one C5 tree 7.2 in Spain growing on the rootstock naturally infected with aphid transmitted PPV became infected. The infected C5 trees in both locations showed very few and relatively mild symptoms; however, differences were observed between the two locations. A characteristic feature of the tree in Spain was significant growth of a nontransgenic branch from the rootstock eventually forming half of the tree structure. This branch became infected and showed symptoms of PPV. Under these extreme conditions of infection pressure, the resistance of C5 was "breached" but not overcome because symptoms only appeared on small shoots very close to the graft union of the $\mathrm{C} 5$ scion and the $P$. marianna rootstock. Symptoms were not observed on other sections of the C5 canopy of this tree, nor were positive results obtained in ELISA or molecular assays. The other C5 trees growing on infected rootstocks remained uninfected through June 2004. Similar to results reported here for tree 7.2, graft-inoculated plants in Romania showed only mild symptoms limited to the leaves growing very close to the point of inoculation (20). In the field trial in Poland, CBI trees F23 and F41 showed mild symptoms on a few leaves. These symptom-expressing leaves were RT-PCR and ELISA positive, although ELISA absorbance values were significantly lower for C5 than for any other clone tested in parallel. Symptomatic leaves could be found on only a few shoots in the entire tree canopy. However, the disease manifestation was not limited to the small area close to the inoculation point. It was possible to detect PPV in some nonsymptomatic leaves by IC-RT-PCR but usually not by ELISA. Most leaves on these trees remained symptomless and tested negative for PPV by ELISA and RT-PCR up to 8 years after inoculation.

The minor, but perceptible difference in the pattern and effectiveness of virus localization in C5 trees that were graft or root sucker inoculated in Poland and Spain perhaps may be attributed to the higher temperature in Spain than in Poland. Szittya et al. (24) reported the influence of low temperature $\left(15^{\circ} \mathrm{C}\right)$ on the suppression of virus gene silencing that may be critical for temperate woody species, particularly in the spring. A further suggestion of this hypothesis was the presence of extremely few and mild symptoms on C5 CBI trees in Poland in 2000 and 2003, 2 years with the highest average daily mean temperatures in April $\left(12^{\circ} \mathrm{C}\right)$ or June $\left(18.2^{\circ} \mathrm{C}\right)$. Furthermore, the average daily maximum temperatures in Skierniewice were $18.9^{\circ} \mathrm{C}$ in April 2000 and $15^{\circ} \mathrm{C}$ or less in all other years. These values seemed to correspond directly to the model proposed by Szittya et al. (24). However, to explain the situation in 2003 (as well as in 2002, another year with few symptoms observed and the highest average mean temperature re- 
corded in May, 17.1 versus 12.5 to $15.4^{\circ} \mathrm{C}$ in the other years), more complex analysis may be needed. Finally, under glasshouse conditions of constant and relatively high temperatures $\left(22\right.$ to $\left.24^{\circ} \mathrm{C}\right), \mathrm{C} 5 \mathrm{did}$ not show symptoms and exhibited negative DAS-ELISA (19).

Compared with the other clones (except $\mathrm{C} 5$ ), clone $\mathrm{C} 4$ exhibited relatively high resistance against aphid inoculation in terms of delay of disease spread in the field. In Poland, all C4 trees eventually became infected between 2002 and 2003, although, from 1999 until 2002, no new infection was observed in this clone. Once C4 trees became infected, they showed leaf symptoms and virus concentrations similar to the susceptible clones. In Spain, nine C4 trees remained uninfected after 6 years, with significant increase in the number of trees infected in year 7 (Fig. 2B). When graft inoculated and tested under greenhouse conditions, clone PT-6 also showed a low level or no ELISA-detectable infection throughout 1 year after inoculation (22). In the Spanish field plot test described here, PT-6 did not show a considerable level of resistance.

Over the course of 7 to 8 years of this study in the two locations, frequent observations of these field plots did not reveal abnormalities in tree growth, flowering, or fruiting in transgenic plum trees. However, it clearly was demonstrated that the transgenic clone C5 was distinct from the other test clones, both transgenic and nontransformed, in its resistance to PPV under high infection pressure. This clone, showing distinguished post-transcriptional gene silencing (PTGS) characteristics $(9,22)$, was able to remain healthy in spite of high natural infection pressure for at least 7 years in the field. This represents a significant part of the productive life of a plum orchard and illustrates the benefits of genetically engineered PTGS for reviving plum production in areas where PPV is endemic.

\section{ACKNOWLEDGMENTS}

This work was supported by grants from EU Commission (BIO4-96-0773 and TRANSVIRQLK3-CT-2002-02140 projects), INIA-RTA03-099 (IVIA/1036) project, and USDA-APHIS. Bilateral co-operation between Poland and France was supported by Polonium project (years 1998-2000). We thank M. C. Martínez, B. Tamargo, J. Picó, G. Szczechowicz, and T. Zielińska for technical assis- tance in the experimental plots; and P. Ferrer from Servicio de Tecnología del Riego (STR), Generalidad Valenciana for the meteorological data of the plot.

\section{LITERATURE CITED}

1. Acuña, R. 1993. Outbreaks of plum pox virus in Chile. Eur. Mediterr. Plant Prot. Org. Conf. Plum pox virus, Bordeaux, France.

2. Asensio, M., Saenz, P., García, J. A., and Cambra, M. 1999. Plum pox virus isolate 3.3 RB/GF-Mp15GF coat protein mRNA, partial cds. GenBank AF172348 (GI: 6049497).

3. Atanassov, D. 1932. Plum pox. A new virus disease. Ann. Univ. Sofia Fac. Agric. Silvic. 11:49-69.

4. Avinent, L., Hermoso de Mendoza, A., and Llácer, G. 1993. Comparison of sampling methods to evaluate aphid populations (Homoptera, Aphidinea) alighting on apricot trees. Agronomie 13:609-613.

5. Boscia, D., Zeramdini, H., Cambra, M., Potere, O., Gorris, M. T., and Myrta, A. 1997. Production and characterization of a monoclonal antibody specific to the $\mathrm{M}$ serotype of plum pox potyvirus. Eur. J. Plant Pathol. 103:477-480.

6. Cambra, M., Asensio, M., Gorris, M. T., Pérez, E., Camarasa, E., García, J. A., López-Moya, J. J., López Abella, D., Vela, C., and Sanz, A. 1994. Detection of plum pox potyvirus using monoclonal antibodies to structural and non structural proteins. Bull. OEPP/EPPO Bull. 24:569-577.

7. Capote, N., and Cambra, M. 2005. Variability of Plum pox virus populations in PPV-resistant transgenic and non-transgenic plums. Phytopathol. Pol. 36:107-113.

8. Clark, M. F. 1981. Immunosorbent assays in plant pathology. Annu. Rev. Phytopathol. 19:83-106.

9. Hily, J.-M., Scorza, R., Malinowski, T., Zawadzka, B., and Ravelonandro, M. 2004. Stability of gene silencing-based resistance to Plum pox virus in transgenic plum (Prunus domestica L.) under field conditions. Transgenic Res. 13(5):427-436.

10. Kassanis, B., and Šutić, D. 1965. Some results of recent investigations on šarka (plum pox) virus disease. Zastita Bilja 16:335-340.

11. Kegler, H., Fuchs, E., Gruntzig, M., and Schwarz, S. 1998. Some results of 50 years of research on the resistance to Plum pox virus. Acta Virol. 42:200-215.

12. Korschineck, I., Himmler, G., Sagl, R., Steinkellner, H., and Katinger, H. W. D. 1991. A PCR membrane spot assay for the detection of plum pox virus RNA in bark of infected trees. J. Virol. Methods 31:139-146.

13. Levy, L., Damsteegt, V., and Welliver, R. 2000. First Report of Plum Pox Virus (Sharka Disease) in Prunus persica in the United States. Plant Dis. 8:202.

14. López-Moya, J. J., Sanz, A., Cambra, M., Gorris, M. T., Anaya, G., Miguet, J. G., Cortés, E., and López-Abellá, D. 1994. Production and characterization of monoclonal antibodies to plum pox virus and their use in differentiation of Mediterranean isolates. Arch. Virol. 135:293-304

15. Malinowski, T. 1997. Silica capture-reverse transcription-polymerase chain reaction (SCRT-PCR): application for the detection of several plant viruses. Pages 445-448 in: Diagnosis and Identification of Plant Pathogens. H. W. Dehne, ed. Kluwer Academic Publishers, Dordrecht, the Netherlands.

16. Malinowski, T., Zawadzka, B., Ravelonandro, M., and Scorza, R. 1998. Preliminary report on the apparent breaking of resistance of a transgenic plum by chip bud inoculation of plum pox virus PPV-S. Acta Virol. 42:241-243.

17. Nemeth, M. 1986. Plum pox (Sharka). Pages 463-478 in: Virus, Mycoplasma and Rickettsia Diseases of Fruit Trees. Akademiai Kiadó, Budapest, Hungary.

18. Neumüller, M., Hartmann, W., and Stösser, R. 2005. The hypersensitivity of European Plum against PPV as a promising mechanism of resistance. Phytopathol. Pol. 36:77-83.

19. Ravelonandro, M., Scorza, R., Bachelier, J.C., Labonne, G., Levy, L., Damsteegt, V., Callahan, A. M., and Dunez, J. 1997. Resistance of transgenic Prunus domestica to plum pox virus infection. Plant Dis. 81:1231-1235.

20. Ravelonandro, M., Scorza, R., Minoiu, N., Zagrai, I., and Platon, I. 2002. Field tests of transgenic plums in Romania. Sănătatea Plant. 6:16-17.

21. Sanford, J. C., and Johnston, S. A. 1985. The concept of parasite-derived resistance-deriving resistance genes from the parasite's own genome. J. Theor. Biol. 113:395-405

22. Scorza, R., Callahan, A., Levy, L., Damsteegt, V., Webb, K., and Ravelonandro, M. 2001. Post-transcriptional gene silencing in plum pox virus resistant transgenic European plum containing the plum pox potyvirus coat protein gene. Transgenic Res. 10:201-209.

23. Scorza, R., Ravelonandro, M., Callahan, A. M., Cordts, J. M., Fuchs, M., Dunez, J., and Gonsalves, D. 1994. Transgenic plums (Prunus domestica L.) express the plum pox virus coat protein gene. Plant Cell Rep. 14:1822.

24. Szittya, G., Silhavy, D., Molnár, A., Havelda, Z., Lovas, Á., Lakatos, L., Bánfalvi, Z., and Burgyán, J., 2003. Low temperature inhibits RNA silencing-mediated defence by the control of siRNA generation. EMBO J. 22:633640.

25. Thompson, D., McCann, M., MacLeod, M., Lye, D., Green, M., and James, D. 2001. First report of plum pox potyvirus in Ontario, Canada. Plant Dis. 85:97.

26. Wetzel, T., Candresse, T., Macquaire, G., Ravelonandro, M., and Dunez, J. 1992. A highly sensitive immunocapture polymerase chain reaction method for plum pox virus detection. J. Virol. Methods 39:27-37.

27. Wypijewski, K., Malinowski, T., Musiał, W., and Augustyniak, J. 1994. The nucleotide sequence of coat protein gene of the Skierniewice isolate of plum pox virus (PPV). Acta Biochim. Pol. 41:87-95. 